\title{
INVESTIGATION OF GAP ADOPTION FOR CHILI GROWERS IN BAAN KAO SUBDISTRICT, SONGKLA PROVINCE, THAILAND
}

\author{
Karnjapan Janthawornpong
}

\author{
Prince of Songkla University, Thailand
}

\begin{abstract}
It is generally required by imported countries that exported agricultural commodities must be complied with Good Agricultural Practices (GAP) standard prior to ensure safe consumption. Baan Kao subdistrict, Ranot district is the largest green chili cultivated area of Songkla province. More than 95\% of green chili from this area is exported to Malaysia and Singapore. The number of GAP certified chili farms in the area is however less than $3 \%$. To investigate such a low certified rate, a semistructured questionnaire survey was conducted in early 2018. One hundred and ten out of one hundred and ninety five chili growing households answered the questionnaire. Ninety seven percent of growers are non-GAP certified. The main reasons for not pursuing GAP certification program are the lack of knowledge about benefit of the program for growers and the belief that participation as well as adoption is time-consuming. Perception and adoption of technologies required for GAP certification survey revealed that 4 technologies i.e. compost use, lime use for soil conditioning, diseased crops elimination, and 7-day pesticides withdrawal period were well perceived by more than $90 \%$ of responders. Only the 7-day withdrawal period was regularly practiced. Nevertheless, responders have good attitude toward minimization of pesticides use. This revealed data would have implication in strengthening agricultural extension program leading to safer chili farming practices.
\end{abstract}

Keywords: Green chili growers, Good Agricultural Practices, investigation

\section{Introduction}

Good Agricultural Practices (GAP) is the collection of principles, relevant regulations, and technical guidelines concerning agricultural production at farm level including the harvesting process and primary management of farm produce. The objectives of GAP standard are for good quality and safety of agricultural produce in considering environmental, economic and social impacts with the aim to attain four major aspects of social interests: food safety, environmental responsibility, animal welfare, and security of people (FAO, 2007).

Depending on the stipulation of its key stakeholders, GAP standard exists at several levels of farm produce customers for example GAP standard required by a specific buyer group: the supermarket group in Indonesia (Zulkarnain et al., 2011), the national standard such as Thai Agricultural Standard or Indo G.A.P. or MyGAP (Malaysian Good Agricultural Practices), the regional standard such as ASEAN GAP standard, and the worldwide global standard such as GLOBAL G.A.P. The standard is varied in detail according to different types of commodity.

Besides the role in shaping good quality and safety of fresh produce (Gravani, 2009), GAP standard also take a role in correcting market failure from improper matching of good quality produce and undifferentiated price by a good flow of production information leading to the valuation of the produce true quality along the whole supply chain (Hobbs, 2003). 
Chili (Capsicum frutescens Linn.) is one of Thailand economic plants for both domestic consumption and export. In 2016, the country export volume of dried chili was 8,000 tons (Office of Agricultural Economics, 2017). The national GAP standard for chili has also been in place since 2005 in order to ensure product safety for consumers and to increase acceptance rate from imported countries (ACFS, 2005). However, most of chili production system in the country is still below GAP standard. The agriculture system is relied heavily on rainfall and natural conditions of land. Chili farmers cultivate plants by using ancestors' derived techniques (Lertrat, 2007). Songkla is one of major chili producers in southern Thailand. Like several other provinces in the country, the number of GAP certified chili planting area in Songkla is quite low comparing to the number of total chili planting area. According to data from the department of agriculture (2017) and the department of agricultural extension of Thailand (2016), chili GAP certified rate of Songkla province was only 4.27\%. This had brought to the objective of the study which was to look into the reasons of such a low chili GAP adoption rate by local growers.

\section{Methodology}

Ranot district is the largest green chili growing area of Songkla province. From all of its 12 subdistricts, Baan Kao subdistrict was the largest chili cultivated area. Therefore, Baan Kao, constisting of 6 villages, was chosen as a representative area to be furthered surveyed.

A semi-structured questionnaire survey was conducted for 6 villages of 195 local green chili growers. The questionnaire consisted of three parts: demographic information, attitude toward the safe chili production group participation, and perception versus practice of recommended technologies by growers regarding GAP adoption. The questionnaire was tested and revised before dissemination to targeted chili growers. List of recommended technologies for which if adopted by farmers will enhance the chance of obtaining GAP certification are as follows:

- $\quad$ Making compost

- Use of enzyme ionic plasma from plants

- Use of enzyme ionic plasma from animals

- Use of plant extracts e.g. lemongrass oil as an insect repellent

- Use of Trichoderma spp. as a biocontrol agent

- Use of a trap for Drasophila melanogaster

- $\quad$ Use of a trap for night butterflies

- $\quad$ Frequent field inspection

- $\quad$ Frequent worms discard

- Use of lime for soil conditioning

- Regular examination of soil quality

- $\quad$ Soaking chili seeds in warm water before growing

- $\quad$ Regularly trimming of plant offshoots

- Diseased crops elimination

- $\quad$ Elimination of aphids by spraying water under leaves

- Reduction of disease or infection by getting rid of leaves near plant roots

- $\quad$ Prevention of plant growth stop by getting rid of flowers near plant roots

- $\quad$ Following the 7-day withdrawal period of pesticides before harvesting 
In addition, heads of chili farmers from villages were interviewed about the situation of GAP adoption by growers and how local chili producers managed to be GAP certified.

\section{Results and discussion}

In Thailand, local vegetable producers including chili growers can become GAP certified primarily by forming a group of safe produce growers in each village. The group receives necessary trainings, know-how transfer related to GAP standard, and some agricultural inputs from local officers of competent authorities. Farmers who follow on GAP requirements are then audited and will be GAP certified by competent authorities if they can achieve all major requirements criteria. On the other hand, in case of failing to meet the criteria, advices for improvement are provided to farmers. A typical approach to obtain GAP certification is presented in Figure 1.

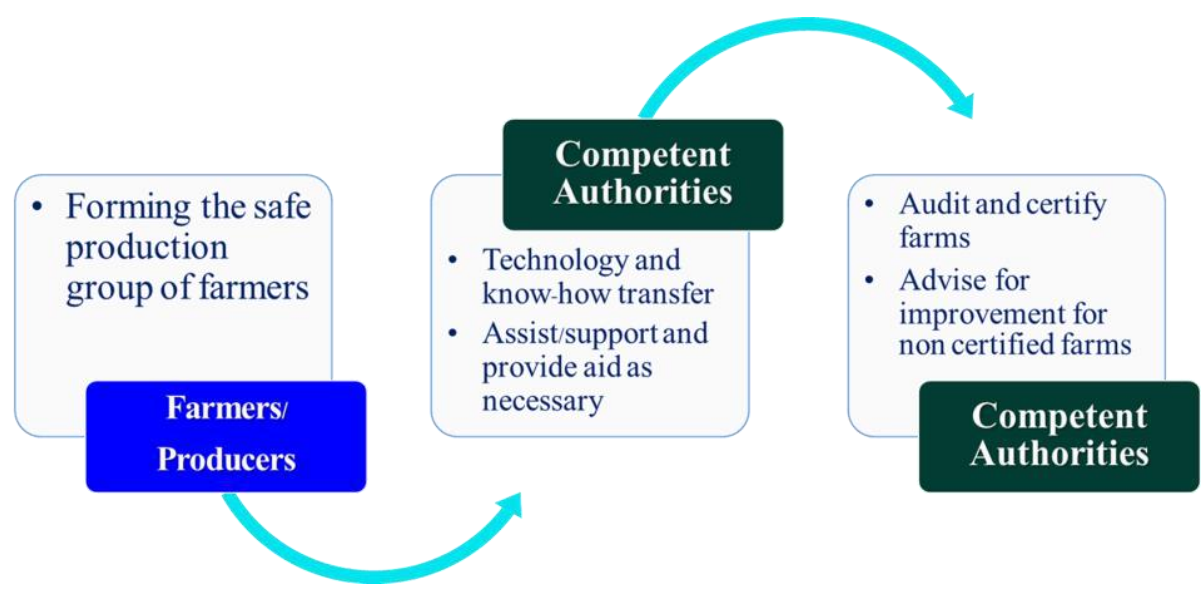

Figure 1 A typical approach for which local chili farmers be GAP certified

The survey was carried out for 195 chili farmers in Baan Kao subdistrict, only 110 green chili growers answered the questionnaire. Information of green chili growers are as shown in Table 1. Most of chili farmers in Baan Kao are the middle-aged female smallholders. Chili is cultivated both for consumption in the household and for exchange. Household debt mainly results from payment of land rent and production inputs e.g. fertilizers, pesticides. Almost all of questionnaire responders are non-GAP certified.

Table 1 Information about Baan Kao chili growers

\begin{tabular}{cccccccccc}
\hline \multicolumn{2}{c}{$\begin{array}{c}\text { Sex } \\
\text { (Persons) }\end{array}$} & Age (years) & Household debt & $\begin{array}{c}\text { Members of the } \\
\text { safe chili } \\
\text { production group } \\
\text { (Persons) }\end{array}$ & $\begin{array}{c}\text { Number of GAP } \\
\text { certified growers } \\
\text { (Persons) }\end{array}$ \\
\hline Male & Female & Mean & Mode & Yes & No & Yes & No & Yes & No \\
\hline 23 & 87 & 49.7 & 39.0 & 91 & 19 & 25 & 85 & 3 & 107 \\
\hline $21 \%$ & $79 \%$ & - & - & $83 \%$ & $17 \%$ & $23 \%$ & $77 \%$ & $3 \%$ & $97 \%$ \\
\hline
\end{tabular}

Participation to the group of safe chili cultivation is the first step for chili farmers to learn about, earn awareness, and therefore prepare for GAP adoption. However, only approximately one fourth of respondents join the group. Reasons to which the respondents made decision join or not to join the group are displayed in Figure 2. In this part of questionnaire, chili growers were allowed to select only one motive which most implied. Two most important reasons chosen by chili growers for becoming members of the safe production group are expecting better price of produce ( $41 \%$ ) and opportunity for obtaining aid from government (37\%). It is understandable that 
agricultural commodities recognized as 'superior class' always have a higher price for which consumers are willing to pay. Conversion made by producers requires administrative support (Tranter et al., 2009). Other interests of group participating are desires to produce safe vegetable (20\%) and to build a professional network $(2 \%)$.

The non-joining group has five distinctive explanations: real benefit to growers is not known (31\%), growers are not available for group participation (29\%), no difference in produce sales price $(23 \%)$, chili is a salable produce $(2 \%)$, and other reasons (15\%) i.e. no sustainably active groups established in the villages and lack of auditors from government agencies to help in group development. Most of chili farmers in Ranot conduct an integrated farming system. This means that chili plants are grown in combination with other plants such as rice and vegetables. Besides plants cultivation, they also do livestock and fish farming. Farmers spend the whole day working in their farms. Consequently, they are not quite interested in attending group activities of which true profits to them have yet to be realized. Although some chili growers have known the advantages of GAP adoption, price of chili is the same for those GAP and non-GAP certified. In addition, there is a small group of growers finding that chili, like other vegetables, has its buyers. It is thus not necessary for growers to put more effort into the produce.
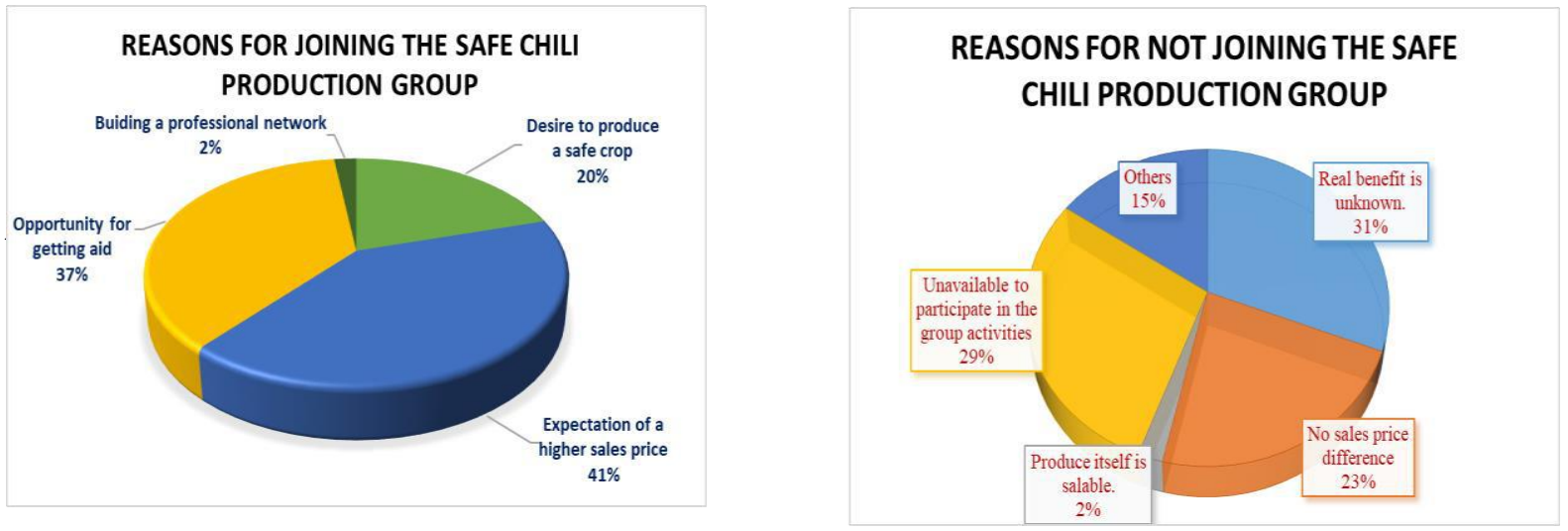

Figure 2 Reasons for joining the safe chili production group (left) and Reasons for not joining the safe chili production group for chili growers of Baan Kao sub district.

Know-hows suggested to be adopted in chili farm are so as to reduce or eventually replace chemical pesticides use. Information about perception and use of these technologies from 110 chili growing respondents are displayed in Figure 3. In this part, respondents had to choose whether they 'know' or 'do not know' and choose whether they 'apply' or 'do not apply' each technique. Farmers could give additional explanation why they did not apply that particular technique in their farm. The result showed that almost all technologies perceived by chili growers have higher percentage than those of practiced technologies except one criterion 'frequent field inspection' of which perception rate was slightly lower than that of practice. This is because a few growers felt unsure about notion and scope of the criterion so they chose 'do not know' rather than 'know' the technique. By the way, most chili farmers well understand and practice regular field inspection. Interestingly, the '7-day withdrawal period' is only 1 out of 18 techniques that received more than $90 \%$ of both perception and practice rates. In this manner, chili farmers respect the necessary interval between pesticides application and crops harvest according to advices from relevant authority or as written on labels of biocidal products. The survey also revealed that chili producers tend to follow guidances that they have realized benefits as well as at their convenience. In this context, growers effortlessly abide by the withdrawal period for the safety of produce and of their own health. On the other hand, when it comes to techniques required more effort from growers such as making enzymes ionic plasma, plant extracts, a biocontrol agent from Trichoderma spp., and insects traps, practice rates of these techniques showed markedly lower than rates of their perception counterparts. Some growers further explained that they needed more trainings before starting to make these organic bio control means on their own and that they expected competent authorities to provide starting materials e.g. Trichoderma spp. as well. Other techniques such as frequent discards 
of worms and diseased crops, water spraying under leaves to eliminate orphids obtained low practice rates due to time and labour consuming nature of the techniques which growers found impracticable when the chili growing area is vast or when the chili growing volume is large. The data shows that there are not many chili growers know about soil quality check before planting and discard of leaves near plant roots to reduce infection. The consequent rate of practice is considerably low. The average percentage of overall technological perception is $70.9 \%$ meanwhile the percentage of overall technological practice is $55.4 \%$.

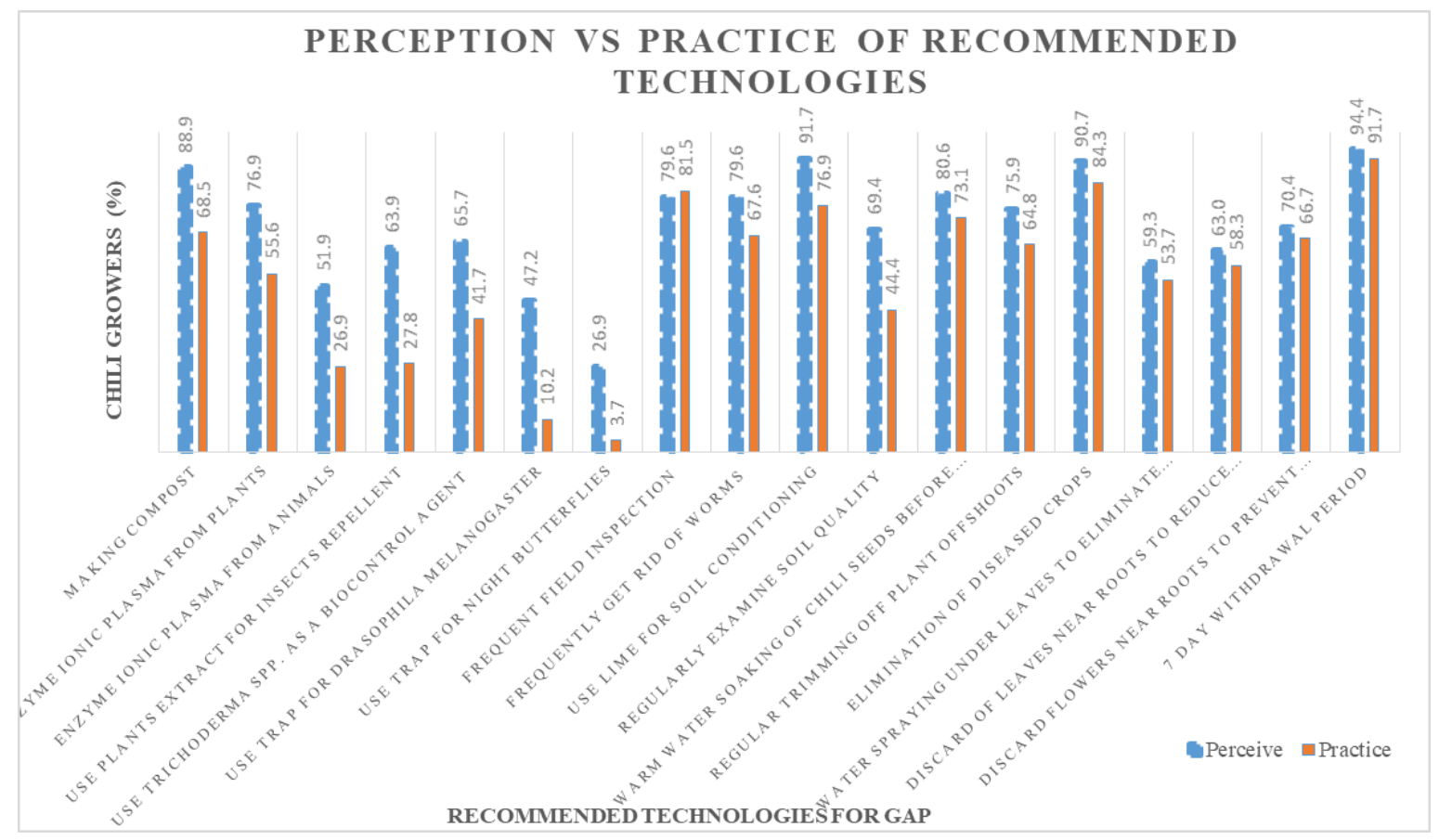

Figure 3 Perception vs Practice of GAP recommended technologies by chili growers of Baan Kao subdistrict.

The difference between these two aspects is not significant as indicated in the case of Basmati (scented) rice GAP adoption (Pandit et al., 2017) due in part to chili growers can indirectly receive the information about GAP from neighbours and acquaintances who adopt the GAP for other types of plants. Moreover, several techniques such as elimination of diseased crops, discard leaves near the roots to prevent infections, trimming of plant offshoots are effortless and easy to understand then apply to their farms.

\section{Conclusions}

GAP standard can be regarded as a contributor of product quality and safety at the upstream of food supply chain. Adoption GAP and eventually obtaining a certification boost domestic and international market acceptance of agricultural products. In this study, GAP adoption of chili growers in Baan Kao sub district was queried. The low GAP adoption rate of chili growers in Baan Kao sub district is mainly associated with low participation rate of growers, at first hand, in the safe chili production group. The majority of chili farmers in survey did not engage into group's activities due to real benefits to them were unrecognized and unavailability of growers themselves. Therefore, there will be a great potential for the department of agricultural extension to develop an effective communication strategy that build awareness of GAP importance among chili farmers. Furthermore, group activities such as meeting, workshop and training should be designed in a less time-consuming and effective way that attract growers attendance. Recommended techniques or technologies facilitate GAP certification if all of them were productively adopted. Relevant authorities should provide more aid to chili growers e.g. Workshops, starting materials for some techniques that require effort from growers to prepare materials before use such as 
those of bio control agents in order to improve technological adoption rates. In addition, competent authorities should pay attention to resolve the problem of insufficient officers who carry out the audit and improvement program in order that chili farmers are able obtain GAP certification. For those chili growers who join the group, their most prominent expectations are to obtain higher sales price and to receive aid from corresponding governmental sector. Pricing mechanism of agricultural commodities like chili involves many factors other than quality and safety of the food produce. This area needs to be further studied.

\section{Acknowledgements}

The author would like to express her gratitude to all chili farmers at Baan Kao sub district and the officers at Ranot agricultural extension office for providing invaluable information. This research work was financially supported by the research and development office, Prince of Songkla University grant no. AGR601370N.

\section{References}

ACFS, National Bureau of Agricultural Commodity and Food Standards, Thai Agricultural Standard (TAS 25022005), 2005, Published in the Royal Gazette, Vol.122. Special Section 117D

Department of Agriculture, 2017. GAP DOA online, Date of access: 06/01/2017. http://gap.doa.go.th/

Department of Agricultural Extension, 2016. Annual report on vegetables production status of vegetables group: chili.

Office of Agricultural Economics, 2017, Dried chili export statistics: monthly quantity and value, Date of access: 10/01/2017. http://www.oae.go.th/oae_report/export_import/export_result.php.

FAO, Guidelines "Good Agricultural Practices for Family Agriculture", Date of access: 07/01/2017. http://www.fao.org/3/a-a1193e.pdf

Gravani, R. B., 2009, The Role of Good Agricultural Practices in Produce Safety, edited by Xuetong Fan, B. A. Niemira, C. J. Doona, F. E. Feeherry, R. B. Gravani. Microbial safety of fresh produce, IFT press (Singapore: Wiley-Blackwell), pp. 101-117.

Hobbs, J.E., 2003, Incentives for the adoption of Good Agricultural Practices (GAPs), Background paper for the FAO expert Consultation on a Good Agricultural Practices approach. Rome, Italy, 10-12 November, 2003.

Lertrat, K. 2007, Production Cultivation Processing and Marketing of chili and chili products in Thailand (in Thai). Date of 10/01/2017. http://www.trf.or.th/index.php?option=com_content\&view=article\&id=904:2013-12-06-12-00-

05\&catid=23:research-forum\&Itemid=218.

Pandit, T., Nain, MS., Singh, R., Kumar, S., Chahal, VP., 2017, Adoption of Good Agricultural Practices (GAPs) in Basmati (Scented) rice: A study of prospects and retrospect. Indian Journal of Agricultural Sciences, 87 (1): 36-41, January 2017/Article.

Tranter, R.B., Bennett, R.M., Costa, L., Cowan, C., Holt, G.C., Jones, P.J., Miele, M., 2009, Consumers' willingness-to-pay for organic conversion-grade food: Evidence from five EU countries. Food Policy, 34, 287294. 
Zulkarnain I., Suleaman A., Ruting A., Koomen I., 2011, Analysis of constraints for compliance to Good Agricultural Practices by the horticultural sector in Indonesia. BOCI Project BO-10-009-109, Date of access: 03/05/2017. http://www.cdi.wur.nl 